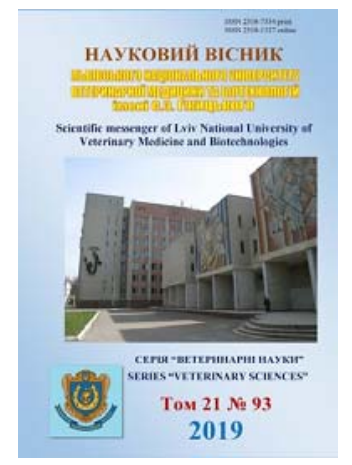

\author{
Науковий вісник Дьвівського національного університету \\ ветеринарної медицини та біотехнологій імені С.З. Гжицького. \\ Серія: Ветеринарні науки
}

Scientific Messenger of Lviv National University of Veterinary Medicine and Biotechnologies. Series: Veterinary sciences

\title{
Study of innate factors in the local immune defense of the genital organs of dogs and cats
}

\author{
M.M. Zhelavskyi \\ Podilya State Agrarian and Engineering University, Kamyanets-Podilsky, Ukraine
}

Article info

Received 01.02.2019

Received in revised form 12.03.2019

Accepted 13.03.2019

Podilya State Agrarian and Engineering University, Shevchenko Str., 13, KamyanetsPodilsky, Khmelnytskyi Region, 32300, Ukraine.

Tel.: +38-097-905-34-23

E-mail: nicoladoctor@gmail.com

Zhelavskyi, M.M. (2019). Study of innate factors in the local immune defense of the genital organs of dogs and cats. Scientific Messenger of Lviv National University of Veterinary Medicine and Biotechnologies. Series: Veterinary sciences, 21(93), 98-102. doi: 10.32718/nvlvet9317

Immune system of reproductive organs of animals is represented by a number of cellular and humoral protection factors. Recently, the attention of scientists was attracted by the role of immunocompetent cells, which integrally provide immune homeostasis at all stages of the reproductive function. The purpose of the work was to study the cellular factors of immune defense of mucous membranes of genital organs of dogs and cats. The cytological composition and determination of immunological parameters of vaginal microscope slide were determined by patented methods. Local immunity was determined by the parameters of extracellular protection mechanisms, which consisted in the study of the Oxygen-dependent potential of neutrophil granulocytes (NBT-test) and their ability to form extracellular traps (NETs). Our studies have found that in different stages of the sexual cycle in beach and cats, along with cytological changes in epithelial cells, changes occur in phagocytic protection. In particular, in the post-infusion period there was an increase in the number of intermediate and basal epithelial cells on the surface of which were adhered microorganisms. Along with epithelial cells, activated phagocytes were grouped. Neutrophils showed cytochemical reactivity in the NBT-test, and also formed NETs. At the same time, activated phagocytes absorbed microorganisms, and some epithelial cells formed specific cytoplasmic inclusions, which obviously also has an important role in the antimicrobial immunity of the mucosa. Some neutrophilic granulocytes were in a state of apoptosis. During the sexual cycle in the organism of dogs and cats there are morphology and functional changes in the genital organs, which was accompanied by a change in the cytological picture of vaginal microscope slides. It was established that the antimicrobial protection system plays an important role in the neutrophilic granulocytes, the functional activity of which also has a change. The main mechanisms of extracellular antimicrobial protection of microphages are realized with the involvement of Oxygen species in the excretion system of active forms and the formation of neutrophilic extracellular traps. Epithelial cells are also involved in the formation of immune homeostasis of genital mucous membranes.

Key words: beach's, cat's, sexual cycle, vaginal microscope slide, phagocytes, antimicrobial potential, NBT-test, NETs.

\section{Introduction}

Immune system of reproductive organs of animals is represented by a number of cellular and humoral protective factors. Recently, scientists from different countries of the world are increasingly attracted by the role of immune cells in the formation of immune homeostasis in the body of animals (Hagman et al., 2009; Sheldon et al., 2010; Voorward et al., 2015). After all, Immune responses are important at all stages of the formation of the reproductive system of animals and have a regulating effect in different periods of their reproductive ability (Silva et al., 2012; Amos et al., 2014; Wira et al., 2015).

It is known that mucous membranes are the oldest natural protection mechanism. The peculiarity of the adaptive immunity of the mucous membranes of the genital organs of animals is that in the process of long evolution, the immune mechanisms have clearly begun to recognize microbial pathogens (Smith et al., 2008; Bien et al., 2012; Krekeler et al., 2012; Wiles et al., 2013; Henriques et al., 2014). The immune system of reproductive organs of animals has also "learned" not to respond to allogeneic sperm and maintains a balance in pregnancy 
(Scheller et al., 2011; Dhakal et al., 2012). Modern science is increasingly replenished with modern data on the physiological significance of gonadotropic and sex hormones on immune responses (Pratschke, 2015).

Recent studies have established the interaction of microorganisms with specific Toll-like receptors (TLR). There is increasing evidence of the importance of epithelial cells in the transport of immunoglobulins ( $\operatorname{IgA}, \operatorname{IgG})$, the transfer of specific signals, the formation of various antimicrobial substances, activation of cellular immunity (Saldaña et al., 2014; Zhelavskyi \& Shunin, 2016; 2017). Despite this, the role of phagocytic cells in the implementation of immune reactions, their participation in the inflammatory process has not yet been fully study (Kruger et al., 2015; Levy et al., 2016; Zhelavskyi \& Shunin, 2018).

The purpose and tasks of the study. The purpose of the work was to study the cellular factors of immune defense of mucous membranes of genital organs of dogs and cats. The task was to study the cytological characteristics of local immunity of genital organs of dogs and cats in different periods of the estral cycle.

\section{Material and methods}

Clinical and experimental studies were performed on dogs of German breed (Canis familiaris, $\mathrm{n}=18$ ) and domestic cats (Felis catus, $\mathrm{n}=23$ ), aged 3 to 7 years old, which were divided into two experimental groups.

The cytological composition and determination of immunological parameters of vaginal microscope slide were determined by patented methods. Local immunity was determined by the parameters of extracellular protection mechanisms, which consisted in the study of the Oxygen-dependent potential of neutrophil granulocytes (NBT-test) (Zhelavskyi \& Shunin, 2016) and their ability to form extracellular traps (NETs) (Zhelavskyi, 2018).

The diagnostic material was taken from the vaginal mucosa using a $15 \mathrm{M}$ phosphate buffer NeoGalin18 using a cytology brush (Zhelavskyi, 2017). To the cell mixture, add $0.05 \mathrm{ml}$ of $0.15 \%$ solution of nitroblue tetrazolium (manufactured by Renal ${ }^{\circledR}$, UK). Subsequently, the cell were incubated for 30 minutes in a wet chamber of the thermostat ( $\mathrm{t} 37^{\circ} \mathrm{C}$ ). After incubation, smears stained with methanol and stained with $0.1 \%$ phosphate buffered NeoGalin18 Neutral Red (pH 7.2) were prepared.

Evaluation and accounting of phagocyte metabolic response (determination of the percentage of reactive neutrophils) was performed by microscopic method (magnification 2000-2500). Reactive (NBT+) neutrophil granulocytes were differentiated by the presence of dark-brown inclusions in the cytoplasm in the form of fine diffuse grains formasane.

In evaluating the functional parameters of extracellular protection factors, the ability of phagocytic cells to form neutrophils extracellular traps (NETs) was also investigated.

This study was approved according to the Law of Ukraine "On the Protection of Animals from Cruel Treatment" (No. 3447-IV of February 21, 2006) and. All animal manipulations were carried out in accordance with the European Convention for the Protection of Vertebrate Animals used for experimental and scientific purposes (Strasbourg, 18 March 1986). All experiments were carried out with the Ethical Permit at the State Agrarian and Engineering University in Podilya. Mathematical processing of research results was processed statistically using the Statistica 10.0 software package (ANOVA).

\section{Results and discussion}

Vaginal cytology in veterinary practice is used to determine (refine) the stage of the sexual cycle, and also is an important approach in the diagnosis of inflammatory processes, infections and oncological diseases of the genital organs. Therefore, it is important for the researcher to know not only the population composition of cells, but also the functional state of phagocytic cells, which form the first line of natural protection of the mucous membrane and ensure the maintenance of immune homeostasis (Silva et al., 2012; Kruger et al., 2015; Zhelavskyi \& Shunin, 2017).

Clinical and experimental studies have established that during the estral cycle of dogs and cats there is a permanent change in the cytological composition in microscope slide of the vaginal mucosa, which had its own characteristic pattern for each stage (Zhelavskyi et al., 2017; Zhelavskyi \& Shunin, 2017).

Microscopy of vaginal drugs during the proestrus showed a gradual dynamic change in individual populations of epithelial cells: At this stage, in vaginal smears, the dominant superficial epithelial cells were $62-68 \%$ in average, and in cats $-33-38 \%$. In some cases (in some $\operatorname{dog} s$ ), in this stage in microscope slides, a significant number of erythrocytes were detected as a result of active hyperemia and diapedesis of the capillaries of the mucous membrane against the background of the peak growth of estradiol. In some fields of view also appeared neutrophils granulocytes.

A characteristic cytological picture for the estrus of the studied small domestic animals is the prevalence of superficial keratinized cells in vaginal microscope slides (dogs $88-91 \%$, cats $82-90 \%$ ). An intensive proliferative process in the epithelial layers of the mucous membrane was accompanied by a characteristic cytological picture, which mainly arose on the background of changes in the ratio of cellular populations of epithelial cells. At the end of the estrus, nuclear superficial epithelial cells and leukocytes have already begun to appear. Under the influence of estrogens, epithelial cells were proliferated and exfoliated. Other cellular structures were found to be intermediate epithelial cells that had larger cytoplasmic size and rounded large nucleus than parabasal epithelial cells. Large interstitial epithelial cells with unchanged nucleus were also differentiated; and superficial, anucleated epithelial cells are cells with characteristic picnotic inclusions in the nucleus.

The beginning of the metestrus in the body of dogs and cats was characterized by a rapid decrease of superficial epithelial cells, which occurred with a parallel in- 
crease in the population of intermediate (Fig. 1) and parabasal epithelial cells. In microscope slides, neutrophil granulocytes were also detected (dogs $73-82 \%$, cats 68 $92 \%$ ). Our previous studies found that neutrophilic granulocytes are the primary inflammatory messengers, which first migrate into the pathological process area and realize their phagocytic function. It is known that the intensity of the inflammatory reaction depends largely on the cascade of immunological reactions in which cellular mechanisms of protection are involved (Zhelavskyi, 2018). Therefore, the functional capacity of phagocytes is an integral indicative value, which fully reflects the manifestation of local

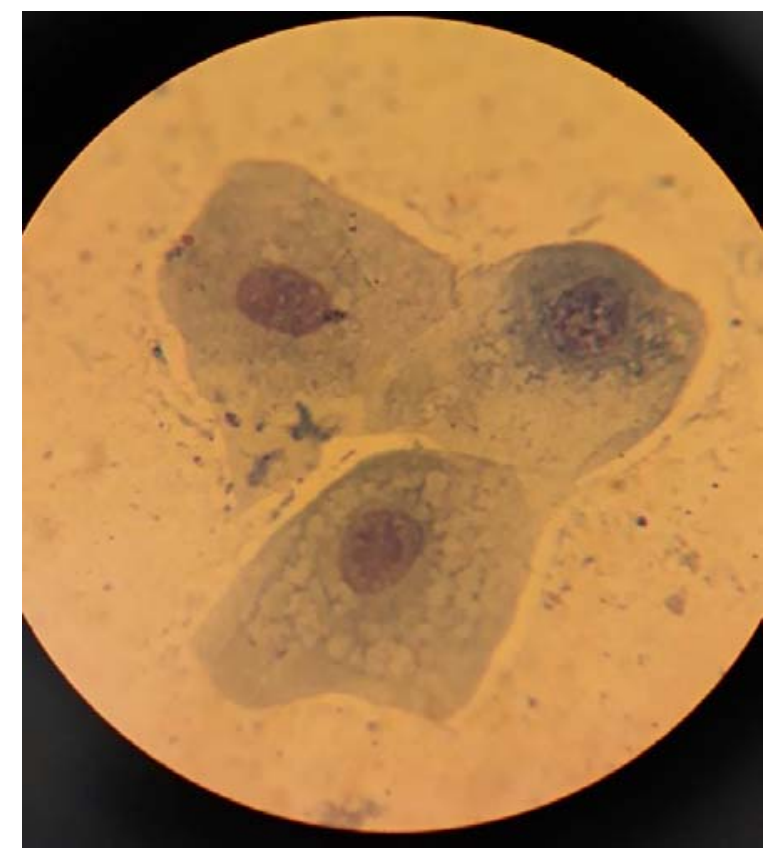

Fig. 1. Vaginal microscope slides of the dog. Intermediate epithelial cells. Staining by own technique (x 2000)

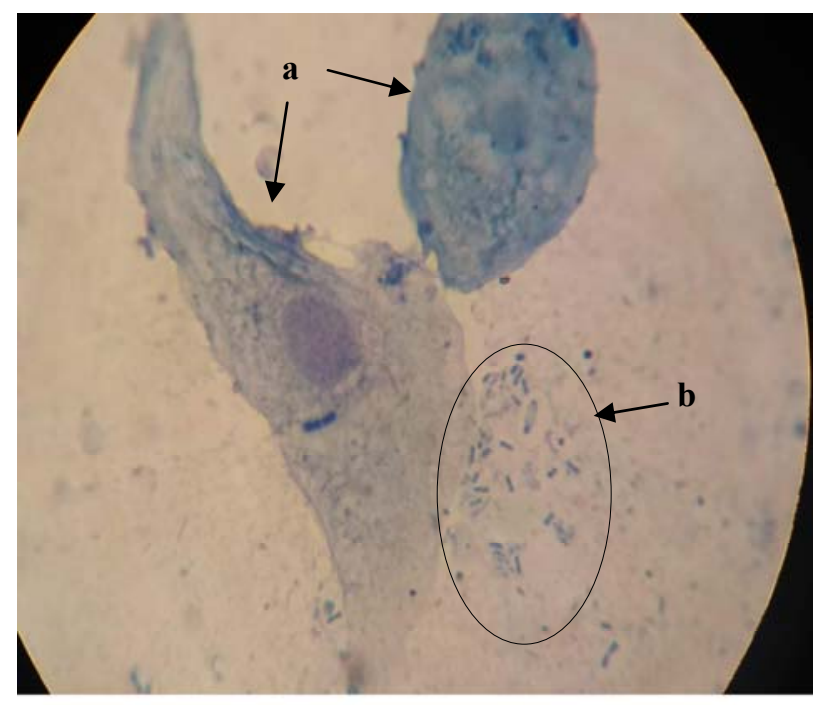

Fig. 3. Vaginal microscope slides of the cats. Keratinized superficial epithelial cells (a) and adhesion of microorganisms (b). Staining by own technique (x 2000) immune defense of the genital organs (Zhelavskyi \& Dmytriv, 2018). Interesting results were obtained in the study of antimicrobial reactivity of microphages in the metestrus stage (NBT-test 9-14\%). Along with epithelial cells, grouped activated phagocytes were detected (Fig. 2).

At the same time, we identified active phagocytes and epithelial cells that were involved in the adhesion and absorption of microorganisms (Fig. 3). Neutrophils in this case were fixed and free formed by extracellular traps (NETs, Fig. 4).

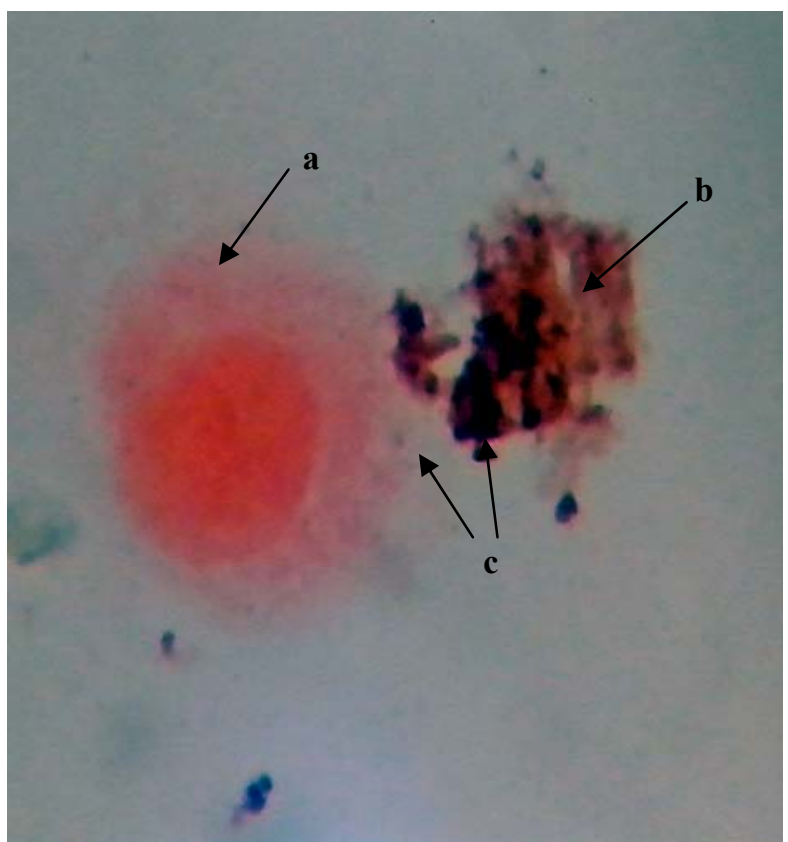

Fig. 2. Vaginal microscope slides of the cats. Parabasal epithelial cell (a) and reactive neutrophil granulocyte (b) with granules of formasane (c). Painting by own technique (x 2500). Staining by own technique (x 2500)

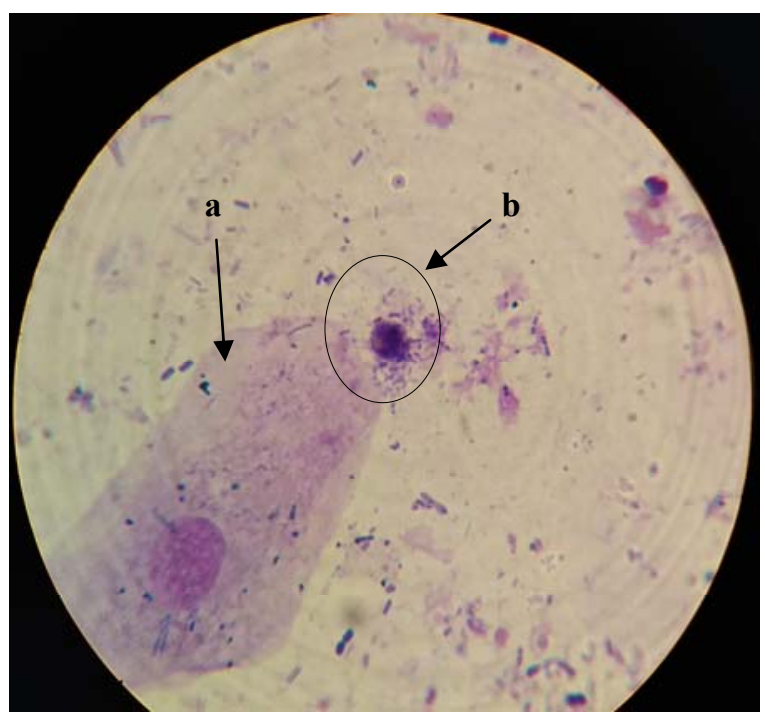

Fig. 4. Vaginal microscope slides of the dogs. Keratinized superficial epithelial cells (a) and neutrophilic granulocyte with extracellular traps (b) (NETs). Staining by own technique (x 2000) 
Separate epithelial cells at the same time had specific cytoplasmic inclusions, which obviously also play an important role in the antimicrobial immunity of the genital mucous membranes (Hagman et al., 2009; Sheldon et al., 2010; Zhelavskyi \& Shunin, 2018). Some neutrophilic granulocytes were at the same time in a state of apoptosis (Zhelavskyi, 2017). This confirms that neutrophil phagocytes provide support for immune homeostasis (Wira et al., 2015; Zhelavskyi \& Shunin, 2017).

\section{Conclusions}

During the sexual cycle in the organism of dogs and cats there are morphology and functional changes in the genital organs, which was accompanied by a change in the cytological picture of vaginal microscope slides. It was established that the antimicrobial protection system plays an important role in the neutrophilic granulocytes, the functional activity of which also has a change. The main mechanisms of extracellular antimicrobial protection of microphages are realized with the involvement of Oxygen species in the excretion system of active forms and the formation of neutrophilic extracellular traps. Epithelial cells are also involved in the formation of immune homeostasis of genital mucous membranes.

Prospects for further research. Further research will be aimed at studying the integral indicators of cellular factors of immune defense of local immunity.

\section{References}

Amos, M., Healey, G., Goldstone, R., Mahan, S., Duvel, A., Schuberth, H., Sandra, O., Zieger, P., DieuzyLabaye, I., Smith, D., \& Sheldon, I. (2014). Differential endometrial cell sensitivity to a cholesterol-dependent cytolysin links Trueperella pyogenes to uterine disease in cattle. Biol Reprod, 90(3), 54. doi: 10.1095/biolreprod.113.115972.

Bien, J., Sokolova, O., \& Bozko, P. (2012). Role of uropathogenic Escherichia coli virulence factors in development of urinary tract infection and kidney damage. Int J Nephrol, 2012, 681473. doi: 10.1155/2012/681473.

Davidson, J. (2015). Small Animal Pyometra. Small An. Sur. Emergencies.

Dhakal, B.K., \& Mulvey, M.A. (2012). The UPEC pore forming toxin $\alpha$-hemolysin triggers proteolysis of host proteins to disrupt cell adhesion., inflammatory and survival pathways. Cell Host Microbe, 11(1), 58-69. doi: 10.1016/j.chom.2011.12.003.

Hagman, R., Rönnberg, E. \& Pejler, G. (2009). Canine uterine bacterial infection induces upregulation of proteolysis-related genes and downregulation of homeobox and zinc finger factors. PLoS One, 4(11), e8039. doi: 10.1371/journal.pone.0008039.

Henriques, S., Silva, E., Lemsaddek, A., Lopes-da-Costa, L., \& Mateus, L. (2014). Genotypic and phenotypic comparison of Escherichia coli from uterine infections with different outcomes: clinical metritis in the cow and pyometra in the bitch. Vet Microbiol, 170(1-2), 109-116. doi: 10.1016/j.vetmic.2014.01.021.

Karlsson, I., Hagman, R., Johannisson, A., Wang, L., Karlstam, E., \& Wernersson, S. (2012). Cytokines as immunological markers for systemic inflammation in dogs with pyometra. Repr. Domest Anim, 47(6), 337341. doi: 10.1111/rda.12034.

Krekeler, N., Marenda, M.S., Browning, G.F., Holden, K.M., Charles J.A., \& Wright P.J. (2012). Uropathogenic virulence factor FimH facilitates binding of uteropathogenic Escherichia coli to canine endometrium. Comp Immunol Microbiol Infect Dis, 35, 461-467. doi: 10.1016/j.cimid.2012.04.001.

Kruger, P., Saffarzadeh, M., Weber, ANR., Rieber, N., Radsak, M., von Bernuth, H., Benarafa, C., Roos, D., Skokowa, J., \& Hartl, D. (2015). Neutrophils: between host defence, immune modulation, and tissue injury. PLoS Pathog, 11, e1004651. doi: 10.1371/journal.ppat.1004651.

Levy, M., Thaiss, C. A., \& Elinav, E. (2016). Metabolites: messengers between the microbiota and the immune system. Genes \& development, 30(14), 1589-1597. doi: 10.1101/gad.284091.116.

Pratschke, K. (2015). Pyometra. Complications in Small Animal Surgery. University of Health Sciences in Pomona, California, USA.

Saldaña, Z., De la Cruz, M.A., Carrillo-Casas, E.M., Durán, L., Zhang, Y., Hernández-Castro, R., Puente, J.L., Daaka, Y., \& Girón, J.A. (2014). Production of the Escherichia coli common pilus by uropathogenic E. coli is associated with adherence to HeLa and HTB-4 cells and invasion of mouse bladder urothelium. PLoS One, 9, e101200. doi: 10.1371/journal.pone.0101200.

Scheller, J., Chalaris, A., Schmidt-Arras, D., \& RoseJohn, S. (2011). The pro and anti-inflammatory properties of the cytokine interleukin-6. Biochim Biophys Acta, 1813(5), 878-888. doi: 10.1016/j.bbamcr.2011.01.034.

Sheldon, I.M., Rycroft, A.N., Dogan, B., Craven, M., Bromfield, J.J., Chandler, A., \& Simpson, K.W. (2010). Specific strains of Escherichia coli are pathogenic for the endometrium of cattle and cause pelvic inflammatory disease in cattle and mice. PLoS One, 5, e9192. doi: 10.1371/journal.pone.0009192.

Silva, E., Henriques, S., Brito, S., Ferreira-Dias, G., Lopes-da-Costa, L., \& Mateus L. (2012). Oestrous cycle-related changes in production of Toll-like receptors and prostaglandins in the canine endometrium. J Reprod Immun, 96(1-2), 45-57. doi: 10.1016/j.jri.2012.07.003.

Smith, Y.C., Rasmussen, S.B., Grande, K.K., Conran, R.M., \& O'Brien, A.D. (2008). Hemolysin of uropathogenic Escherichia coli evokes extensive shedding of the uroepithelium and hemorrhage in bladder tissue within the first $24 \mathrm{~h}$ after intraurethral inoculation of mice. Infect Immunol, 76(7), 29782990. doi: 10.1128/IAI.00075-08.

Voorward, F., Marchi, F., Villacis, R., Alves, C., Toniollo, G., Amorim, R., Drigo, S., \& Rogatto, S. (2015). 
Molecular expresson profile reveals potential biomarkers and therapeutic targets in canine endometrial lesions. PLoS One, 10, e0133894. doi: 10.1371/journal.pone.0133894.

Wiles, T.J., \& Mulvey, M.A. (2013). The RTX poreforming toxin alpha-hemolysin of uropathogenic Escherichia coli. Fut. Microbiol, 8, 73-84. doi: $10.2217 / \mathrm{fmb} .12 .131$.

Wira, C.R., Rodriguez-Garcia, M., Patel, M.V., Biswas, N., \& Fahey, J.V. (2015). Endocrine regulation of the mucosal immune system in the female reproductive tract. In Mucosal Immunology, 2, 2141-2156. doi: 10.1016/B978-0-12-415847-4.00110-5.

Zhelavskyi, M. (2018). Changes in the immunobiological reactivity of the organism of cows in the pathogenesis of mastitis. Scientific Messenger of Lviv National University of Veterinary Medicine and Biotechnologies. Series: Veterinary Sciences, 20(83). 77-82. doi: $10.15421 /$ nvlvet8315.

Zhelavskyi, M.M. (2017). Ontogenetic features of the formation of local immune protection of the mammary gland of cows (literature review and original research). Scientific Messenger of Lviv National University of Veterinary Medicine and Biotechnologies, 19(78), 3-8. doi: $10.15421 /$ nvlvet7801.

Zhelavskyi, M.M., \& Shunin I.M. (2016). Sposib otsiniuvannia lokalnoho imunitetu statevykh orhaniv u tvaryn. Patent Ukrainy N 109040. 2016 Ver 15. http://base.uipv.org/searchINV/search.php?action=vie wdetails\&IdClaim=223881 (in Ukrainian).

Zhelavskyi, M.M. (2018). Sposib tsytokhimichnoi diahnostyky kistozno-fibroznoi khvoroby molochnoi zalozy kishok i sobak. Patent Ukrainy N 125978, 2018 Ver $10 . \quad$ http://base.uipv.org/searchINV/ search.php?action=viewdetails $\&$ IdClaim $=247803 \quad$ (in Ukrainian).

Zhelavskyi, M.M., \& Dmytriv, O.Ya. (2018). Immunobiological status of the body of cows during mastitis. Scientific Messenger of Lviv National University of Veterinary Medicine and Biotechnology, 20(88), 3-10. doi: 10.15421/nvlvet8801.

Zhelavskyi, M.M., \& Shunin, I.M. (2017). Clinical use of Aglepristone for treatment of open-cervix pyometra in cats. Scientific Messenger of Lviv National University of Veterinary Medicine and Biotechnologies, 19(78), 9-12. doi: 10.15421/nvlvet7802.

Zhelavskyi, M.M., \& Shunin, I.M. (2016). Stan klitynnykh faktoriv lokalnoho imunitetu slyzovoi obolonky pikhvy u kishok. Naukovyi visnyk Lvivskoho natsionalnoho universytetu veterynarnoi medytsyny ta biotekhnolohii, 18, 1(65), 32-36. https://nvlvet.com.ua/index.php/journal/article/view/4 0 (in Ukrainian).

Zhelavskyi, M.M., \& Shunin, I.M. (2017). The status of extracellular antimicrobial potential of phagocytes genitals of cats. Scientific Messenger of Lviv National University of Veterinary Medicine and Biotechnologies, 19(73), 71-74. doi: 10.15421/nvlvet7315.

Zhelavskyi, M.M., \& Shunin, I.M. (2018). Doslidzhennia tsytolohichnykh markeriv piometry kishok. Veterynariia, tekhnolohii u tvarynnytstva i pryrodokorystuvannia, 1, 73-76. https://hdzva.edu.ua/ wp-content/uploads/2018/08/vttp20181.pdf (in Ukrainian).

Zhelavskyi, M.M., Shunin, I.M., \& Smoliak, D.V. (2017). Shchodo vdoskonalennia tsytolohichnoho metodu otsiniuvannia klitynnykh faktoriv lokalnoho imunitetu reproduktyvnykh orhaniv tvaryn. Zbirnyk naukovykh prats mizhnarodnoi naukovo-praktychnoi konferentsii "Ahrarna nauka ta osvita Podillia". 14-16 bereznia 2017; Kamianets-Podilskyi: Podilskyi derzhavnyi ahrarno-tekhnichnyi universytet, 1, 325-326. http://188.190.33.56:7980/jspui/handle/123456789/26 83 (in Ukrainian).

Zhelavskyi, M.M. (2017). Sposib tsytokhimichnoi diahnostyky apoptozu klityn reproduktyvnoi systemy tvaryn. Patent Ukrainy N 114100. 2017 Ver 4 http://base.uipv.org/searchINV/search.php?action=vie wdetails\&IdClaim=232672 (in Ukrainian).

Zhelavskyi, M.M. (2017). Sposib tsytokhimichnoi diahnostyky piometry. Patent Ukrainy N 114094. 2017 Ver 4 http://base.uipv.org/searchINV/ search.php?action=viewdetails\&IdClaim=232666 (in Ukrainian).

Zhelavskyi, M.M. (2017). Sposib tsytolohichnoi vizualizatsii ta otsiniuvannia neitrofilnykh ekstratseliuliarnykh pastok slyzovoi obolonky statevykh orhaniv tvaryn. Patent Ukrainy N 119915. 2017 Ver 19. http://base.uipv.org/searchINV/ search.php?action=viewdetails\&IdClaim=240071 (in Ukrainian).

Zhelavskyi, N.N., \& Shunin, I.N. (2017). Sostojanie jekstracelljuljarnogo protivomikrobnogo potenciala fagocitov polovyh organov u koshek. Sbornik nauchnyh trudov Vitebskoj gosudarstvennoj akademii veterinarnoj mediciny, 65-69. http://www.vsavm.by/wp-content/uploads/2013/11/ Sbornik-Mejd-konf-Persp-akt-ye-probl-razv2017.pdf (in Russian). 